\title{
Atresia Ani (Imperforated Anus) in Calves: Clinical, Surgical and Pathological Aspects
}

\author{
Maria Eduarda dos Santos Lopes Fernandes $\odot^{1}$, Saulo Andrade Caldas ${ }^{2}$, Letícia Ramos Rocha ${ }^{3}$, \\ Marina Galindo Chenard ${ }_{\odot}^{4}$, Kelly Regina Freitas Freire ${ }_{\odot}^{1}$, Nathália da Silva Carvalho ${ }_{\odot}{ }^{1}$, \\ Vivian de Assunção Nogueira ${ }^{5}$ \& Michel Abdalla Helayel $\oplus^{6}$
}

\begin{abstract}
Background: Anal atresia is a congenital malformation, which often affects calves, and is related to the imperforation of the membrane that separates the endoderm of the posterior intestine from the ectodermal anal membrane. It is commonly associated with other congenital malformations and skeletal anomalies. The clinical signs generally appear in the first days of the animal's life, due to a retention of feces. The diagnosis is clinical and is based on observation, anamnesis and a physical examination of the animal. The only viable treatment is surgical. This paper aims to report 6 cases of anal atresia in bovine calves, 4 males and 2 females that were successfully treated surgically.

Cases: This work reports 6 cases of anal atresia in 4 male calves and 2 female calves. Three presented total atresia (type II), one partial (type I) and in both female calves, anal atresia and rectovaginal fistula (type IV) were observed. The animals were all of undefined race. Five of the cases were from northern Tocantins, 4 males and 1 female (anal atresia with rectovaginal fistula), and 1 female (anal atresia with rectovaginal fistula) was from Valença, RJ. All animals were born active, by eutocic/natural birth, and assumed a quadrupedal position followed by the first feeding as normal. They were aged between 2 days and 6 months, and had a clinical history of abdominal distention and difficulty or inability defecating, and the females both also had a rectovaginal fistula, all cases compatible with anal atresia. Based on the patient's history and clinical examination, surgical treatment for anal reconstruction was decided upon. Postoperative treatment consisted of enrofloxacin $[2.5 \mathrm{mg} / \mathrm{kg}$ - intramuscularly (IM), once daily (SID), for 5 days] and fluxinin meglumine [1.1 mg/kg - IM, SID, for 3 days] ; as well as a healing ointment which was applied to the area of the surgical wound, every $12 \mathrm{~h}$, for 7 days. There were no trans-surgical complications. The animals showed progressive recovery after anal reconstruction and the stitches were removed in all cases on the $10^{\text {th }}$ postoperative day, with no postoperative complications and no recurrence of any clinical signs from that moment on.

Discussion: The study of congenital and hereditary changes enables the identification of their origins, can help prevent new cases and, some of them, are open to economically viable treatment and/or correction that can improve the well-being of the animal and prevent economic losses due to death or animal sacrifice, as reported in the present study. Anal atresia is the most common congenital defect of the lower gastrointestinal tract in calves, being an isolated abnormality, or associated with other malformations, especially of the distal spinal column such as the absence of a tail (perosomus acaudatus), as one of the animals in this study. The clinical signs and physical examination are sufficient to establish the diagnosis, as demonstrated in this report, which is usually made in newborn animals, due to the lack or difficulty in defecation associated with no anal orifice and/or swelling in the perineal region. The treatment of choice for anal atresia is surgical, in order to construct an anal neo-orifice and thus avoid endotoxemic shock as well as providing relief and well-being for the animals. As observed in this study, when anal atresia is diagnosed early, and surgical treatment is properly instituted, the prognosis is favorable. The surgery is considered of low complexity, quick and it can be carried out in the field. Thus, from a commercial point of view, considering the costs of the procedures and the value of the calf at the end of weaning, such treatments are beneficial to the owners. In addition, the surgical treatment is essential for animal health and welfare in cases of anal atresia.
\end{abstract}

Keywords: cattle, congenital defects, hereditary pathology, perosomus acaudatus, surgery.

${ }^{1}$ Programa de Pós-Graduação em Medicina Veterinária; ${ }^{2}$ Departamento de Medicina e Cirurgia Veterinária (DMCV) \& ${ }^{5}$ Departamento de Epidemiologia e Saúde Pública (DESP), Universidade Federal Rural do Rio de Janeiro (UFRRJ), Seropédica, RJ, Brazil. ${ }^{3}$ Faculdade de Veterinária; ${ }^{4}$ Programa de Pós-Graduação em Medicina Veterinária \& ${ }^{6}$ Departamento de Saúde Coletiva Veterinária e Saúde Pública (MSV), Universidade Federal Fluminense (UFF), Niterói, RJ. CORRESPONDENCE: M.E.S.L.Fernandes [dudalopesfer@hotmail.com] \& S.A. Caldas [sauloacaldas@hotmail.com]. Instituto de Veterinária - UFRRJ. BR-465, Km 07. CEP 23890-000 Seropédica, RJ, Brazil. 
M.E.S.L. Fernandes, S.A. Caldas, L.R. Rocha, et al. 2021. Atresia Ani (Imperforated Anus) in Calves: Clinical, Surgical and Pathological Aspects

Acta Scientiae Veterinariae. 49(Suppl 1): 681

\section{INTRODUCTION}

Anal atresia is a congenital defect, frequently described in calves and piglets [1], characterized by total or partial occlusion of the anal orifice, which may or may not be accompanied by other congenital malformations such as the absence of the final portion of the rectum and tail (perosomus acaudatus) [5]. Anal atresia is due to the absence of an opening in the membrane that separates the endoderm of the posterior intestine from the ectodermal anal membrane [1].

In animals with anal atresia, the clinical signs are generally evident soon after birth [13] and the diagnosis is supported by noting evacuation difficulties or the absence of defecation. These signs are associated with the clinical lack of an anal orifice, abdominal distention, swelling in the perineal region, tenesmus and weakness $[11,12]$. The only treatment option is surgical reconstruction, using the anoplasty technique, which has favorable results depending on the type of atresia and early intervention [13].

The objective of this work is to describe 6 cases of anal atresia in bovine calves, 5 from the northern region of Tocantins State and 1 from the State of Rio de Janeiro (RJ). Furthermore, we discuss the clinical, pathological and surgical aspects of this congenital condition.

\section{CASES}

This work reports 6 cases of anal atresia in 4 male calves and 2 female calves. Three presented total atresia (type II), 1 partial (type I) and in both female calves, anal atresia and rectovaginal fistula (type IV) were observed. The animals were all of undefined race.
Five of the cases were seen at the Veterinary University Hospital of the School of Veterinary Medicine and Zootechnics at the Federal University of Tocantins (HVUEMVZ / UFT), 4 males and 1 female (anal atresia with rectovaginal fistula) and 1 female (anal atresia with rectovaginal fistula) was from the Veterinary Hospital of Fundação Dom Educacional Dom André Arco Verde in Valença - RJ (HV/FAA). All animals were born active, by eutocic/natural birth, and assumed a quadrupedal position followed by the first feeding as normal.

In all the 6 cases, the animals underwent clinical examinations, which diagnosed anal atresia. After which the animals were referred for surgery. In each case, they were subjected to $12 \mathrm{~h}$ of fasting and $6 \mathrm{~h}$ of water fasting. At the time of surgery, the animals were premedicated with an association of $2 \%$ xylazine $^{1}$ [Sedanew $\left.{ }^{\circledR}-0.04 \mathrm{mg} / \mathrm{kg}, \mathrm{IM}\right]$ and $1 \%$ acepromazine $^{1}$ [Acepran ${ }^{\circledR}-0.06 \mathrm{mg} / \mathrm{kg}$, IM]. Epidural anesthesia was performed in the sacrococcygeal space, with an application of $4 \mathrm{~mL}$ of $2 \%$ lidocaine $^{2}$ [Lidovet $^{\circledR}-0.1 \mathrm{~mL} / \mathrm{kg}$, Epidural] followed by trichotomy and antisepsis of the surgical field.

The 3 cases (Cases 1, 2 and 3) of total atresia (type II) were seen at the HVU-EMVZ / UFT. These cases were male bovine calves aged from 3 to 45 days old and weighed from 30 to $40 \mathrm{~kg}$. The owners reported that they noticed the absence of the anal orifice, and in 1 of the animals the absence of a tail (perosomus acaudatus) on the day they were born. The owner of the animal with anal atresia and perosomus acaudatus reported that he tried to make an incision in the topographic region of the anal orifice; however, without success. The clinical examination in all 3 cases reported the absence of the anal orifice (Figure 1) and

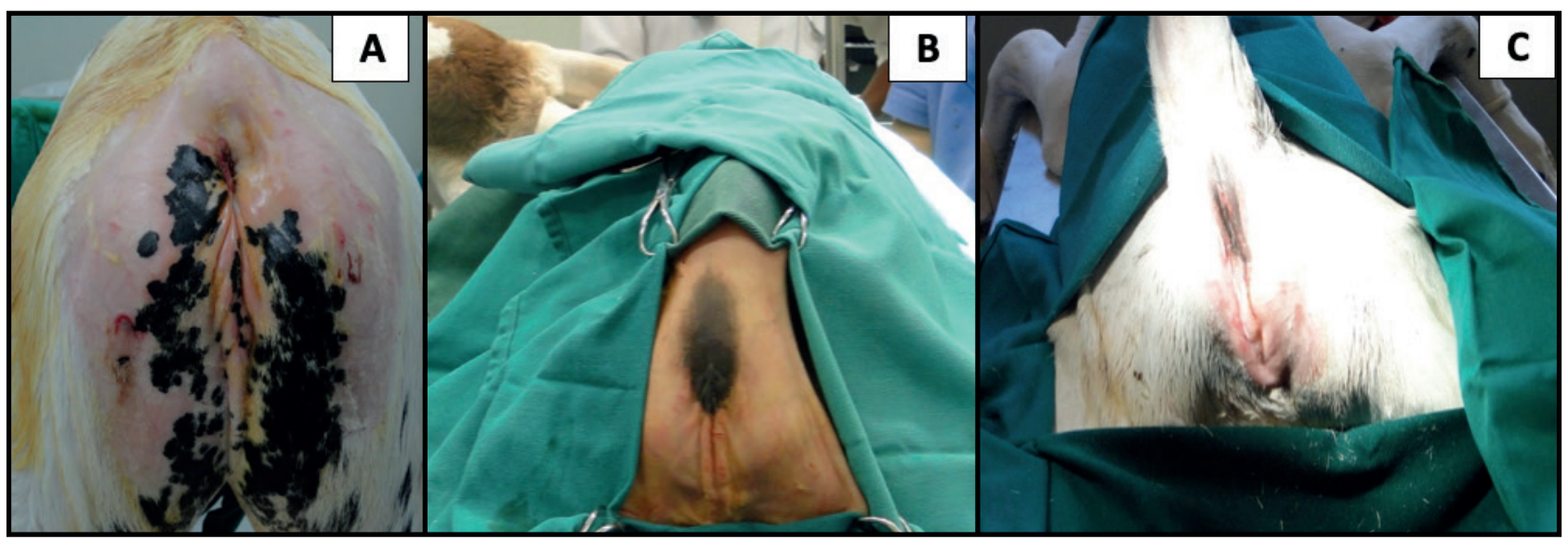

Figure 1. Three calves (A, B \& C) attended at HVU-EMVZ/UFT. A- Case 1: calf with total anal atresia (type II) and without a tail (perosomus acaudatus). B \& C- Cases 2 \& 3: calves with total anal atresia (type II). 
M.E.S.L. Fernandes, S.A. Caldas, L.R. Rocha, et al. 2021. Atresia Ani (Imperforated Anus) in Calves: Clinical, Surgical and

slight abdominal distention, while all the other clinical parameters were normal.

The same surgical technique was applied in these 3 cases. First the surgical field was prepared, and then a cross incision was made in the topographic region of the anal orifice. Subsequently, the subcutaneous cell tissue was thoroughly divulsed until the rectum was located (type II anal atresia) [Figure 2]. Anchoring sutures were placed at the four cardinal points, fixing the seromuscular layer of the intestinal bowel loop to the subcutaneous cellular tissue adjacent to the rectal topography. Subsequently, an incision was made in the rectum wall (enterotomy) with the insertion of gauze pads in the neo-orifice to prevent leakage of feces into the surgical field. The mucosa was sutured to the skin, with the primary stitches at the 4 cardinal points, followed by stitches in the intermediary points using a simple interrupted suture with 3-0 non-absorbable monofilament thread (mononylon) ${ }^{3}$ [Shalon $\left.{ }^{\circledR}\right]$.

The case of partial atresia (type I) [Case 4] was diagnosed at the HVU-EMVZ/UFT in a 6-month-old male bovine that had difficulty in defecating. Clinical examination revealed defecation difficulties, tenesmus, back arching, stenosis of the anal orifice (type I atresia) and dilation of the rectal ampoule; and, consequently, the animal was referred for surgery.

The surgical procedure started with a circular suture in the skin that was stenosing the rectal orifice. Subcutaneous cell tissue was thoroughly divulsed to locate the serosa of the rectum. The rectal wall was

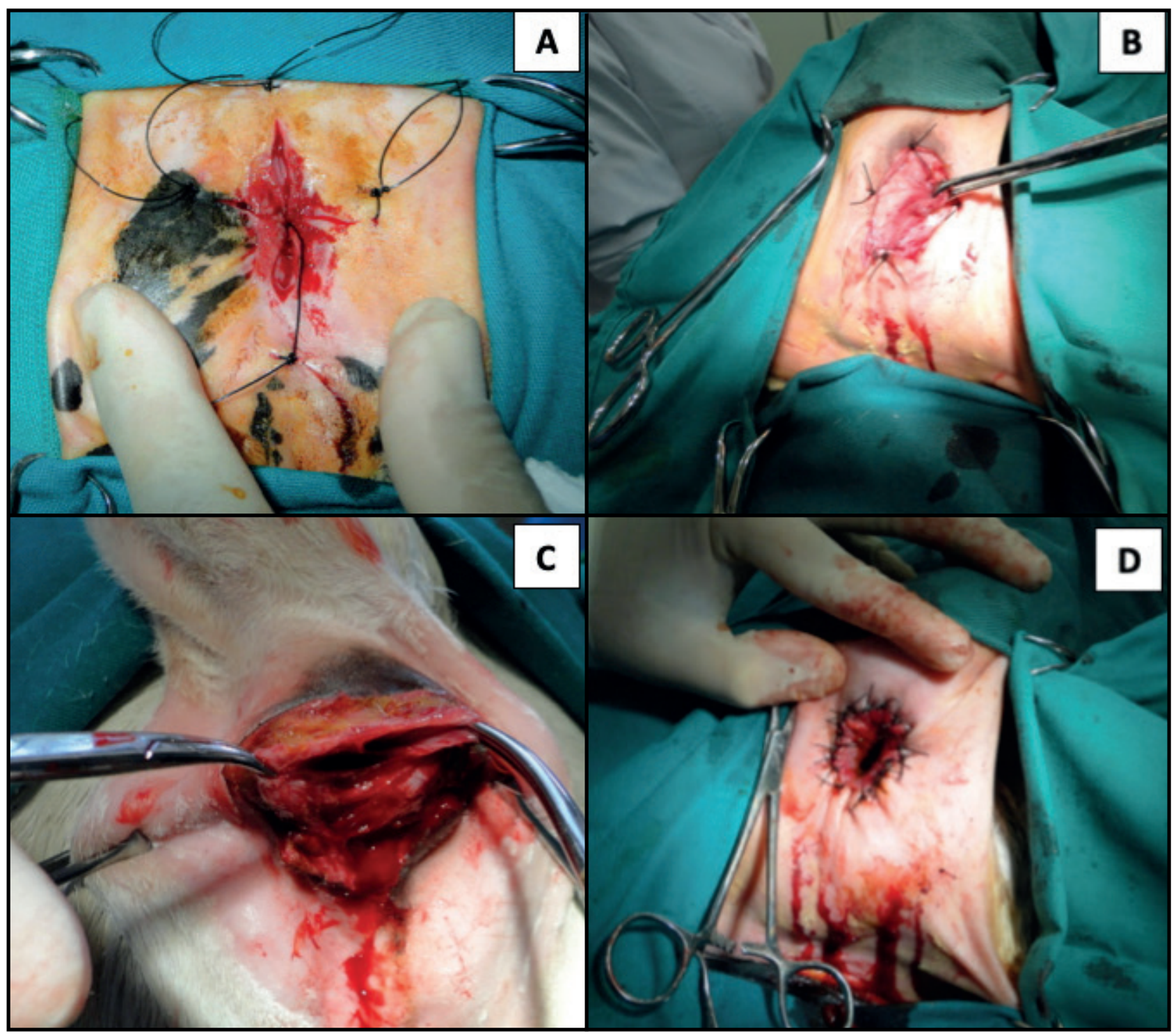

Figure 2. Surgical steps to correct the total anal atresia (type II) in 3 calves (Cases 1, 2 and 3) seen at the HVU-EMVZ/UFT. A- Cross cutaneous incision in the topographic region of the rectal orifice. B- Divulsion of the subcutaneous cell tissue to locate the rectum. C- Location of the rectum, followed by an enterotomy to construct the anal neo-orifice. D- Suture of the rectum mucosa to the skin forming an anal neo-orifice. 
M.E.S.L. Fernandes, S.A. Caldas, L.R. Rocha, et al. 2021. Atresia Ani (Imperforated Anus) in Calves: Clinical, Surgical and

pulled caudally back until a portion of the same intestinal segment with a larger diameter was located. The procedures for anchoring and suturing the intestinal segment wall to the anal neo-orifice were the same as those described in the previous cases (Figure 3).

The 2 female calves with anal atresia also presented rectovaginal fistula. They both had slight abdominal distension and the feces passed through the vulva. The animals were about 5 days old, and weighed approximately $40 \mathrm{~kg}$. One was treated at the HV/FAA (Case 5) and the other at HVU-EMVZ/UFT (Case 6).
The clinical examination of both animals showed that all clinical parameters were within the physiological values for the species. After the identification and clinical diagnosis of anal atresia had been made, they were immediately referred for surgery. Initially, a cross incision was made in the topographic region of the anal orifice. Subsequently, the subcutaneous cell tissue was thoroughly divulsed until the rectum was located (type IV anal atresia) [Figure 4]. Anchoring suture was performed at the 4 cardinal points, fixing the seromuscular layer of the intestinal loop to the

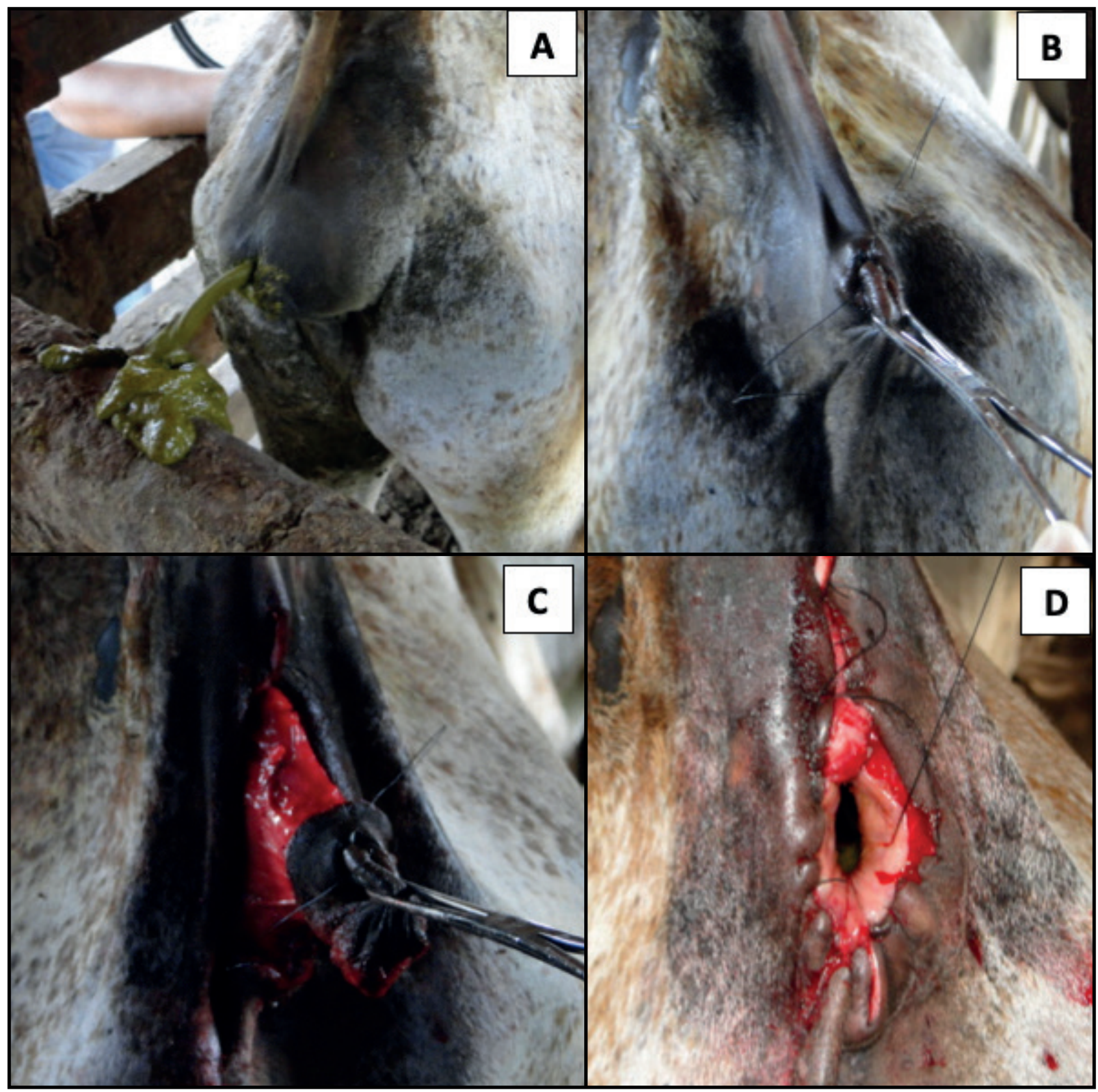

Figure 3. Surgical steps to correct a partial anal atresia (type I) in a calf (Case 4) treated at the HVU-EMVZ/UFT. A- Stenosis of the anal orifice and dilation of the rectal ampoule when defecating. B- Circular suture in the skin that was stenosing the anal orifice. C- Divulsion of subcutaneous cell tissue and location of the rectum serosa. D- Anchoring and suturing the intestinal segment wall to the skin to form an anal neo-orifice. 
M.E.S.L. Fernandes, S.A. Caldas, L.R. Rocha, et al. 2021. Atresia Ani (Imperforated Anus) in Calves: Clinical, Surgical and

subcutaneous cellular tissue adjacent to the rectal topography. Subsequently, an incision was made in the rectum wall (enterotomy) with the insertion of gauze in the orifice to prevent any leakage of feces into the surgical field. The mucosa was sutured to the skin at the 4 cardinal points, followed by stitches at the intermediate points using a simple interrupted suture with 3-0 non-absorbable monofilament thread (mononylon) $\left[\text { Shalon }^{\circledR}\right]^{3}$. In order to close the rectovaginal orifice, an episiotomy was initially performed on the dorsal commissure to gain access to the neo-orifice. Then its edges were incised and closed with 3-0 non-absorbable, monofilament sutures (mononylon) in a single stitch pattern (Figure 4).

The postoperative period followed the same procedures in all 6 cases, and consisted of antimicrobial therapy based on enrofloxacin ${ }^{4} 10 \%$ [Baytril $^{\circledR}$ $2.5 \mathrm{mg} / \mathrm{kg}$, IM, once daily, SID, for 5 days] and fluxinin meglumine $^{5}$ [Flunixin ${ }^{\circledR} 1.1 \mathrm{mg} / \mathrm{kg}$, via IM, SID, for 3 days]. An ointment ${ }^{4}$ [Ultraproct ${ }^{\circledR}$ ], composed of fluocortolone pivalate, fluocortolone caproate, cinchocaine hydrochloride and clemizole undecylate, was applied to the area of the surgical wound, every $12 \mathrm{~h}$, for 7 days.

The time to perform the anoplasty procedures in Cases 1, 2, 3 and 4 was on average 30 to $45 \mathrm{~min}$ and in Cases 5 and 6 (with rectovaginal fistula) 45 to $60 \mathrm{~min}$. Based on the materials used, and without considering the cost of the veterinarians, the average value of the procedure per animal (average weight $40 \mathrm{~kg}$ ) was estimated at US\$ 3.27. This overall cost was based on $0.08 \mathrm{~mL}$ of $2 \%$ xylazine (US\$ 0.032 ), $0.24 \mathrm{~mL}$ of $1 \%$ acepromazine (US\$ 0.048 ), $4 \mathrm{~mL}$ of $2 \%$ lidocaine (US\$ 0.23), $5 \mathrm{~mL}$ of enroflaxacin 10\% (US\$ 0.45), 2.64 $\mathrm{mL}$ of fluxinin meglumine (US\$ 0.64), $3.5 \mathrm{~g}$ of healing ointment (US\$ 0.37), a scalpel blade No. 24 (US\$ 0.08) and 4 nylon (3-0) thread envelopes (US\$ 1.42).

The animals showed progressive recovery after anal reconstruction (anoplasty) and the stitches were removed in all cases on the $10^{\text {th }}$ postoperative day, with no postoperative complications and no recurrence of any clinical signs from that moment on.

\section{DISCUSSION}

Congenital defects occur in $0.5 \%$ to $3 \%$ of newborn cattle, and anomalies associated with the gastrointestinal and urogenital tracts are the most common $[3,4]$. There has been an increased interest in the study of congenital and hereditary defects in Brazil recently due to a growth in the numbers of cases, some of which are open to treatment $[2,4]$. The study of congenital and hereditary changes (is very important as it) enables the identification of their origins, can help prevent new cases and, some of them, are open to economically viable treatment and/or correction. Such treatments can improve the well-being of the animal, and prevent economic losses due to death or animal sacrifice as reported in the present study.

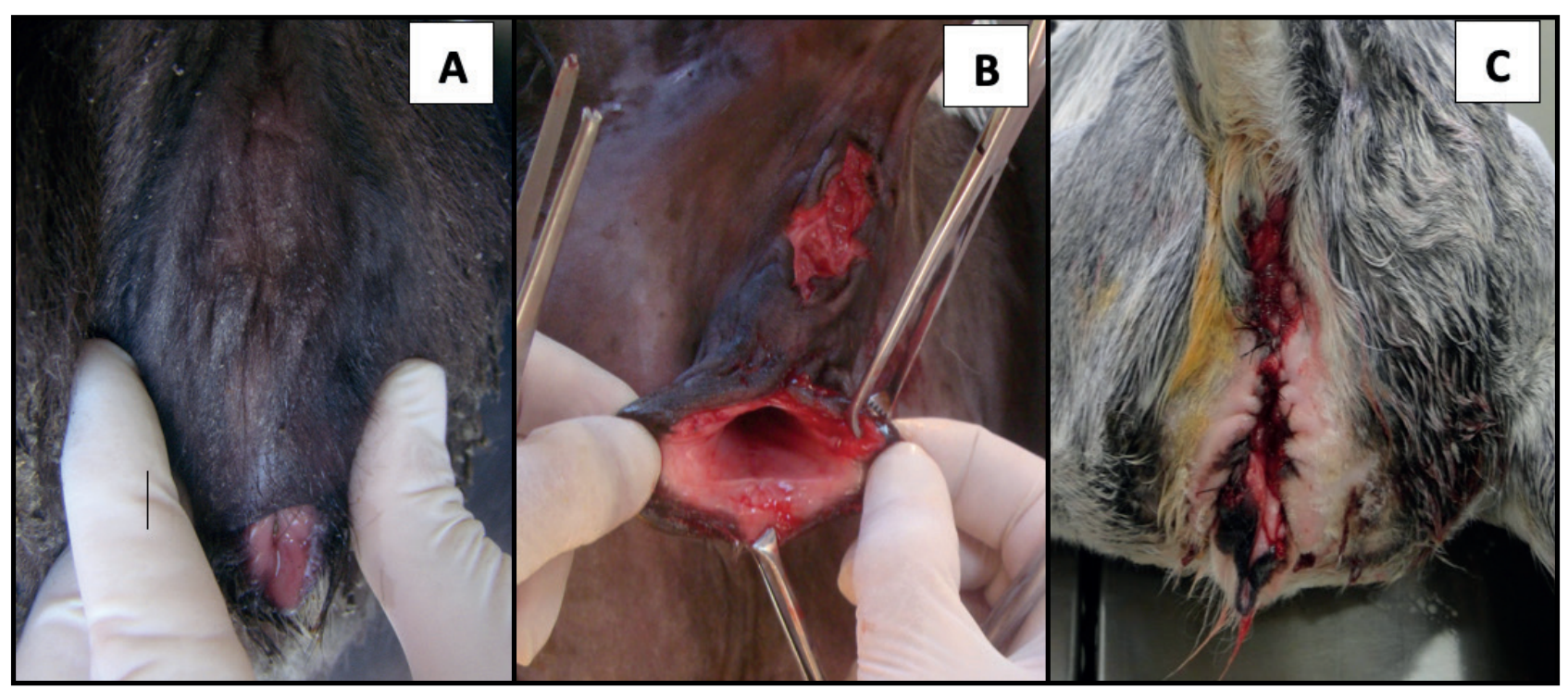

Figure 4. Surgical steps to correct an anal atresia with a rectovaginal fistula (type IV) in 2 female calves (Cases 5 and 6) seen at HVU-EMVZ/UFT and at Hospital Veterinário FAA. A- Case 5: a heifer with an anal atresia and rectovaginal fistula (type IV) seen at Hospital Veterinário FAA, before surgery. B- Divulsion of subcutaneous cell tissue to locate the rectum, followed by an episiotomy at the dorsal commissure to observe the rectovaginal fistula. C- Case 6: heifer with an anal atresia and rectovaginal fistula (type IV) seen at the HVU-EMVZ / UFT, after the surgical procedure. 
Four (Cases 1, 2, 3 and 4) of the 6 cases of anal atresia occurred in male calves. The literature mentions that anal atresia is the most common congenital defect of the lower gastrointestinal tract [5] that affects several species, and is more common in male calves, in which it is considered inheritable $[1,13]$. In males, it is usually lethal, unless treated early, while in females it is not life threatening, due to the possible association with rectovaginal fistula [14].

Anal atresia can be an isolated abnormality, but it may also be associated with other malformations, especially of the distal spinal column such as the absence of a tail (perosomus acaudatus) [1], as observed in Case 4 of this report. However, unlike Case 4 reported here, the occurrence of anal atresia associated with perosomus acaudatus is more common in females [8].

Anal atresia has 4 classifications (I to IV), according to the degree of dysgenesis or agenesis of the rectum and anus [10]. Type I, observed in Case 4 of this study, is characterized by a normal rectum and a stenotic anus [10]. In this case, despite the difficulty of defecation, this function is preserved thus allowing the animal to live and maintain a certain degree of health for a longer time. This corroborates with Case 4 , where surgical treatment was only carried out when the animal was 6 months old. In type II, observed in the first 3 reported cases, the anal membrane was intact, and the rectum ended in a blind pouch cranially to the imperforated anus, while in type III the blind pouch of the rectum is even more cranial, usually within the pelvic cavity [10]. In type IV, the rectum ends as an early pouch within the pelvic canal and the terminal rectum and anus develop normally. In such cases there can be a communication between the rectum and the urogenital apparatus [3], as described in Cases 5 and 6 , where these 2 female calves presented rectovaginal fistulas, in addition to anal atresia.

The rectovaginal fistula, presented by the 2 female calves in this study, is a fistulous tract between the vagina and the rectum that is a result of anal atresia and the increased fecal pressure within the rectum [3]. The signs presented by the calves in this report, such as the passage of feces through the vulva and signs of colonic obstruction suggested the occurrence of anal atresia. The identification of the fistula, its surgical correction and the restoration of normal anatomical structures are imperative, and unlike the cases reported in this article, the prognosis is generally reserved.
Complications, such as fecal and urinary incontinences are frequently observed [3]; however, such complications did not occur in this study.

Absence of defecation, tenesmus, depression, varying degrees of abdominal distention, abdominal pain, spinal arch and endotoxemic shock are some of the most common clinical signs seen in animals with anal atresia $[11,12]$. In the cases of total anal atresia (type II) reported in this study, the clinical signs presented were mild, most likely due to the short period of evolution, and the early diagnosis of the condition. The most significant signs observed were the absence of defecation and abdominal distension.

In the present report, all cases of anal atresia, with or without rectovaginal fistula, were diagnosed based on clinical evaluations. According to the literature, the clinical signs and physical examination are sufficient to establish the diagnosis, which is usually made in animals 2 or 3 days old, due to the lack or difficulty in defecation associated with no anal orifice and/or swelling in the perineal region [11,14]. Exams, such as radiography and ultrasound, can also assist in the diagnosis by helping to identify the position of the colon and rectum in relation to the perianal region [15].

The treatment of choice for anal atresia is surgical, in order to construct an anal neo-orifice (anoplasty) and thus avoid endotoxemic shock as well as providing relief and well-being for the animals [13]. There are several known techniques used to correct anal atresia in calves [13]. In this work, a modified anoplasty technique was used in the animals with type II and IV atresia, where instead of removing a circular fragment of skin over the anal region, an incision in the shape of a "+" was made, and in the calves with rectovaginal fistula an episiotomy was performed to correct the fistula. In the calf with type I anal atresia, the classic anoplasty technique was applied, which involved removing a circular cutaneous fragment over the anal region. Both the above mentioned techniques have been described as having good postoperative results, without complications such as stenosis and recurrence of the condition $[6,7,9]$, exactly as occurred in the cases presented in this report. Cases of anal atresia that undergo surgical intervention prior to the start of any important systemic changes, such as the animals in this study, generally present a satisfactory prognosis, as long as good surgical practices are maintained in order to minimize trans and postoperative 
complications; such as contamination. However, if suitable treatment is not made early, the prognosis of the animals becomes unfavorable, since this condition is life threatening.

The early veterinary assistance given in the first days of the animals' life was essential for the positive outcome of the total anal atresia cases (types II and IV) reported in this study; since the impossibility of defecation can be fatal for the animal. In the case of partial anal atresia (type I), surgical therapy was instituted after several months of the animal's life, also successfully; however, the animal managed to survive because it was still capable of defecating, even if only partially. All animals in the present report responded well to the surgical procedures and had a good recovery with no post-surgical complications or recurrence of the clinical condition.

Reports demonstrating the positive outcomes of interventions in congenital disorders are extremely important, since such disorders are frequent in farm animals. Congenital disorders are often neglected or attempts to carry out therapeutic treatments are discouraged. However, it should be remembered that treatment costs are advantageous as the prognosis is favorable, when surgical treatment is established early. Thus, from a commercial point of view, considering that the costs of the procedures are minimal compared to the value of the calf at the end of weaning; such treatments are beneficial to the owners. In addition, animal health and welfare must be taken into account, especially considering that some cattle are currently being raised as pets. The surgery is of low complexity, quick and it can be carried out in the field.

Considering that these problems could well be of genetic origin, ideally, these animals should be sterilized so that the problem is not propagated in the herd. Furthermore, an early referral of animals to the veterinary hospital, in cases of anal atresia, is crucial before any serious systemic changes appear to ensure a good prognosis.

\section{MANUFACTURERS}

${ }^{1}$ Vetnil Indústria e Comércio De Produtos Veterinários Ltda. Louveira, SP, Brazil.

${ }^{2}$ Laboratório Bravet Ltda. Rio de Janeiro, RJ, Brazil.

${ }^{3}$ Shalon Fios Cirúrgicos Ltda. São Luís de Montes Belos, GO, Brazil.

${ }^{4}$ Bayer AG. Wuppertal, RN, Germany.

${ }^{5}$ Chemitec Agro-Veterinária Ltda. Ipiranga, SP, Brazil.

\section{REFERENCES}

1 Brown C.C., Baker D.C. \& Baker I.K. 2007. Alimentary system. In: Jubb K.V.F., Kennedy P.C. \& Palmer N. (Eds). Pathology of Domestic Animals. 5th edn. New York: Academic Press, pp.3-296.

2 Campos F.K., Sousa M.G.S, Silva N.S., Oliveira C.H.S., Duarte M.D., Barbosa J.D. \& Oliveira C.M.C. 2009. Doenças congênitas em bovinos diagnosticadas pela central de diagnóstico veterinário (cedivet) da Universidade Federal do Pará, no período de 1999 a 2009. Ciência Animal Brasileira. 1: 13-18.

3 Carvalho Y.N.T., Branco M.A.C., Mota L.H.C.M., Evangelista L.S.M., Silva S.V. \& Feitosa Júnior F.S. 2012. Atresia Anal Associada à Fístula reto-vaginal em Bezerra: Uma Revisão. PUBVET. 6(33): 1-15.

4 Dantas A.F.M., Riet-correa F., Medeiros R.M.T., Galiza G.J.N., Pimentel L.A., Anjos B.L. \& Mota R.A 2010. Malformações congênitas em ruminantes no semiárido do nordeste brasileiro. Pesquisa Veterinária Brasileira. 30(10): 807-815.

5 Debasis J. \& Mousumi J. 2010. Perosomus acaudatus (Anury) in a local non-descript milch cow: A report. North East Veterinarian. 10: 1-25.

6 Gangwar A.K., Devi K.S., Singh A.K., Katiyar N., Patel G. \& Srivastava S. 2014. Congenital anomalies and their surgical correction in ruminants. Advances in Animal and Veterinary Sciences. 2(7): 369-376.

7 Kumar G., Arora N., Tiwari D.K., Shamar S. \& Kaushik D. 2020. Surgical management of atresia ani complicated with rectovaginal fistula in a Sahiwal calf. Journal of Entomology and Zoology Studies. 8(3): 714-716.

8 Macêdo J.T.S.A., Lucena R.B., Giaretta P.R., Kommers G.D., Fighera R.A., Irigoyen L.F. \& Barros C.S.L. 2011. Defeitos Congênitos em Bovinos da Região Central do Rio Grande do Sul. Pesquisa Veterinária Brasileira. 31(4): 297-306.

9 Mahesh R., Kamalakar G. \& Devi P.V. 2014. Surgical management of atresia ani in a calf: a case report. International Journal of Agricultural Sciences and Veterinary Medicine. 2(2): 51-53.

10 Remi-adewunmi B.D., Fale M.S., Usman B. \& Lawal M. 2007. A retrospective study of atresia ani cases at the Ahamdu Bello University veterinary teaching hospital Zaria, Nigeria. Nigerian Veterinary Journal. 28(1): 48-53. 
M.E.S.L. Fernandes, S.A. Caldas, L.R. Rocha, et al. 2021. Atresia Ani (Imperforated Anus) in Calves: Clinical, Surgical and Pathological Aspects Acta Scientiae Veterinariae. 49(Suppl 1): 681

11 Shakoor A., Muhammad S.A., Younus M. \& Kashif M. 2012. Surgical repair of congenital recto-vaginal fistula with atresia ani in a cow calf. Pakistan Veterinary Journal. 32(2): 298-300.

12 Singh J., Singh A.P., Patil D.B. \& Kelawala D.N. 2020. The digestive system. In: Singh J., Singh S. \& Tyagi R.P.S. (Eds). Ruminant Surgery. 2nd edn. New Delhi: CBS Publisher and Distributors, pp.292-337.

13 Singh N.K., Kumar A. \& Kumar P. 2018. Surgical correction of atresia ani et recti along with pervious urachus in sahiwal cow calves. Journal of Natural Science, Biology and Medicine. 9(2): 288-290.

14 Weaver A.D., Jean G.S. \& Steiner A. 2005. In: Bovine Surgery and Lameness. 2nd edn. Oxford: Blackwell Publishing, pp.75-139.

15 Yanaka R., Ferreira H.N., Assis M.M.Q., Oliveira G.K., Albuquerque V.B. \& Sartori V.C. 2012. Defeitos congênitos múltiplos em bezerros nelore - Relato de caso. Revista Arquivos Veterinária. 28(3): 144-147. 